\title{
Comparing bone tissue engineering efficacy of HDPSCs, HBMSCs on 3D biomimetic ABM-P-15 scaffolds in vitro and in vivo
}

\author{
Yamuna Mohanram • Jingying Zhang $\cdot$ Eleftherios Tsiridis $\cdot$ Xuebin B. Yang $\mathbb{D}$
}

Received: 6 April 2020/Accepted: 19 July 2020/Published online: 20 August 2020

(C) The Author(s) 2020

\begin{abstract}
Human bone marrow mesenchymal stem cells (HBMSCs) has been the gold standard for bone regeneration. However, the low proliferation rate and long doubling time limited its clinical applications. This study aims to compare the bone tissue engineering efficacy of human dental pulp stem cells (HDPSCs) with HBMSCs in 2D, and 3D anorganic bone mineral (ABM) coated with a biomimetic collagen peptide (ABM-P-15) for improving boneforming speed and efficacy in vitro and in vivo. The multipotential of both HDPSCs and HBMSCs have been compared in vitro. The bone formation of HDPSCs on ABM-P-15 was tested using in vivo model. The osteogenic potential of the cells was confirmed by alkaline phosphatase (ALP) and immunohistological staining for osteogenic markers. Enhanced ALP, collagen, lipid droplet, or
\end{abstract}

Y. Mohanram · J. Zhang $\cdot$ X. B. Yang $(\varangle)$

Biomaterials \& Tissue Engineering Group, Department of Oral Biology, School of Dentistry, University of Leeds, Level 7, Wellcome Trust Brenner Building, St. James's University Hospital, Leeds LS9 7TF, UK

e-mail: X.B.Yang@leeds.ac.uk

J. Zhang

The Second Clinical Medical College, Guangdong

Medical University, Dongguan 523808,

Guangdong, China

E. Tsiridis

Academic Orthopaedic Department, Aristotle University Medical School, 54124 Thessaloniki, Greece glycosaminoglycans production were visible in HDPSCs and HBMSCs after osteogenic, adipogenic and chondrogenic induction. HDPSC showed stronger ALP staining compared to HBMSCs. Confocal images showed more viable HDPSCs on both ABM-P-15 and ABM scaffolds compared to HBMSCs on similar scaffolds. ABM-P-15 enhanced cell attachment/ spreading/bridging formation on ABM-P-15 scaffolds and significantly increased quantitative ALP specific activities of the HDPSCs and HBMSCs. After 8 weeks in vivo implantation in diffusion chamber model, the HDPSCs on ABM-P-15 scaffolds showed extensive high organised collagenous matrix formation that was positive for COL-I and OCN compared to ABM alone. In conclusion, the HDPSCs have a higher proliferation rate and better osteogenic capacity, which indicated the potential of combining HDPSCs with ABM-P-15 scaffolds for improving bone regeneration speed and efficacy.

Keywords PepGen P-15 - HDPSCs · HBMSCs · Bone tissue engineering $\cdot$ In vivo

\section{Introduction}

The increasing clinical demand for bone regeneration and repair in the context of our ageing population poses a challenge both to healthcare providers and 
society (Iaquinta et al. 2019). There is also increasing demand for the implant osseointegration, which is crucial for successful implantology in both orthopaedics and dentistry (Chandran and John 2019; Liu et al. 2019). Tissue engineering provides a promising strategy to meet this clinical demand by developing functional bone construct using stem/stromal cells, biomimetic biomaterial scaffolds, with/without growth factors (Abdulghani and Mitchell 2019). However, the main challenge is to identify the most appropriate combination of the three elements that can be used to achieve optimum regeneration of damaged bone tissue (Panetta et al. 2009).

Under in vitro conditions, mesenchymal stem cells (MSCs) exhibit the ability to form fibroblastic colonies on tissue culture plastic (Gothard et al. 2013) and can differentiate alone osteoblast, chondrocyte, adipocytes, and other different lineages when cultured under the appreciate inductive media (GarciaSanchez et al. 2019). HBMSCs has been considered as one of the most popular stem cell sources for stem cells therapy and bone tissue engineering (Connolly et al. 1989; Kern et al. 2006; Squillaro et al. 2016; Yoshii et al. 2009). However, bone marrow biopsy/aspiration itself is an invasive procedure, and in elderly patients, they often lack good quality and quantity of desired stem cells within the bone marrow (Yamada et al. 2014). It has been documented that the poor response of these cells is due to the loss of potential to proliferate and differentiate with increasing donor age (Jones and Schafer 2015; Kern et al. 2006; Muschler et al. 2001; Yamada et al. 2010; Yoshii et al. 2009). Taken together, these factors have led to the search for an alternative adult stem cell sources which can be easily accessed with minimal invasion and provide the stem cells with similar or better regenerative potential as HBMSCs. In nature, every individual, during their lifetime, experiences teeth loss (80\% of subjects had lost one or more tooth, and the mean tooth loss was 5.09)(Ribeiro et al. 2015), which provides an opportunity to access dental tissues with minimal invasion making the option of isolating of stem cells from dental pulp a promising alternative source to HBMSCs. Pulp tissues can be obtained from either permanent or deciduous teeth, however, wisdom teeth (third molars) have long been a preferred choice of the permanent teeth (Ledesma-Martinez et al. 2016). This may due to the third molars are routinely extracted due to impaction caused by the lack of jaw space, and it is also the last permanent teeth to erupt, and their pulp tissue is considered to be rich in unspecialised cells (Gronthos et al. 2000; Ledesma-Martinez et al. 2016). A number of studies showed that HDPSCs is a small population of cells residing in the pulp tissue which exhibits a highly proliferative and multi-lineage differentiation ability (Cui et al. 2014; Gronthos et al. 2000; Mortada and Mortada 2018). These cells are thought to play a role in the repair of damaged pulp and dentine by differentiating into specialised cellsodontoblasts secreting dentine matrix. Extensive research has since been carried out pursuant to a good understanding of HDPSCs and their potential in tissue engineering (Kawashima and Okiji 2016).

In natural conditions, type I collagen is predominantly present in the bone extracellular matrix. It not only provides the substrate for cell attachment and migration but also influences the osteogenic differentiation of the adhered cells. Thus, there has been an increasing interest in the application of type I collagen for bone tissue engineering (Weisgerber et al. 2016). Structurally, individual type I collagen molecules are triple helical structures, comprising of two $\alpha 1$ and one $\alpha 2$ polypeptide chains. Each of these chains contains approximately 1000 amino acid residues and is twisted into a right-handed helix. A number of studies have shown that the exposed half turns of the helical structure act as cell-binding sites, through which collagen interacts with cell surface integrin receptors (Murray et al. 2003; Rodwell and Kennelly 2000; Xu et al. 2000). As a result, collagen triggers the signalling pathway to direct the cells in attachment, migration and osteogenic differentiation (Bhatnagar et al. 1999b; Emsley et al. 2000). A synthetic analogue of this cell-binding domain was produced synthetically to mimic the function of the collagen molecule under in vitro conditions for osteogenic induction in cells. This synthetic protein is referred to as "peptide 15" or "P-15" (Bhatnagar et al. 1999b, 1997; Scaria et al. 1989). The function of P-15 on its own has been tested on osteoblastic cell lines-MG63 and HBMSCs (Carinci et al. 2004; Sollazzo et al. 2009). Based on microarray analysis, osteoblastic cells were observed to up-regulate fibronectin, cell cycle and signal transduction related genes after culture in P-15 (Carinci et al. 2004). P-15 peptide under in vitro conditions was observed to function similar to the collagen by influencing the up-regulation of bonespecific proteins in HBMSCs. 
In the case of bone regeneration, it is anticipated that an ideal bone graft substitute provides all the essential features of an autologous bone graft, including both the organic and inorganic components of the natural bone. With this concept in mind, a threedimensional scaffold material was designed by incorporating P-15 peptides on ABM particles, a natural xenogenic source of hydroxyapatite (HA) (Bhatnagar et al. 1999b). These bovine bone chips are pre-treated at high temperatures to remove the organic components of the bone, leaving only the inorganic components (Bhatnagar et al. 1999b; Hofmann et al. 2007; Yuan et al. 2007), which is the major inorganic constituent of natural bone (Neshati et al. 2012). ABM-P-15 mimics the structural framework of the autologous bone graft by supplying both the cellbinding domain of type I collagen and HA for the growth of the cells. To date, ABM-P-15 scaffolds have been successfully tested on both animal models and on humans (Emecen et al. 2009), which demonstrated that P-15 adsorbed on ABM scaffolds enhanced attachment, growth and osteogenic differentiation of the tested cells when compared with ABM scaffolds alone. By far, extensive work has been carried out on the application of ABM-P-15 scaffolds on its own and using different cell types for bone tissue engineering application (Barboza et al. 2002; Lindley et al. 2010; Mardas et al. 2008; Matos et al. 2011; Sarahrudi et al. 2008; Scarano et al. 2003; Thorwarth et al. 2005; Vastardis et al. 2005; Yang et al. 2004). The aim of this study was to compare the osteogenic potential of HDPSCs with HBMSCs and the effect of P-15 on the bone-forming capacity of HDPSCs in vitro and in vivo for the potential of combining these two to improve the bone regeneration efficacy in the clinical setting.

\section{Materials and methods}

Tissue culture reagents were obtained from Corning Life Sciences B.V. (The Netherlands). Alpha-modified minimal essential media $(\alpha-M E M)$ without Lglutamine was purchased from Lonza (UK) and fetal bovine serum (FBS) was from Biosera (UK). Molecular biology reagents were purchased from Invitrogen (UK). Dexamethasone, alkaline phosphatase kits, and all other biochemical reagents were of analytical grade from Sigma (UK) unless otherwise stated.
Scaffold synthesis and preparation

Two types of scaffolds were used in this study: anorganic bovine mineral (Osteo-Graf/N-300) absorbed with/without P-15, which are FDA approved for the dental application and are commercially available as PepGen P-15 ${ }^{\circledR}$ (Cerapedics, Inc. CO, USA). The particles are described in our previous paper (Yang et al. 2004). The 48 well tissue culture plates were coated with $12 \%$ poly(2-hydroxyethyl methacrylate)(Poly Sciences, PA) to prevent cell attachment to the plastic. $35 \mathrm{mg}$ of ABM-P-15 or $\mathrm{ABM}$ particles were transferred into the well and sterilised using UV radiations for $30 \mathrm{~min}$.

\section{Isolation and culture of HDPSCs and HBMSCs}

Sound third molar teeth were extracted at Leeds School of Dentistry with patients' informed consent and ethical approval (LREC 07/H1306/93). A total of 20 human teeth was collected (average age: $24 \pm 4$ years). HDPSCs were isolated and in vitro expanded as previously described (El-Gendy et al. 2013, 2015; Gronthos et al. 2000; Ricordi et al. 1992). 4 human bone marrow samples (average age: $59 \pm 16$ years) were obtained from routine total hip replacement patients at Leeds General Infirmary and Chapel Allerton Hospital with patients' informed consent ethical approval by the NHS local ethical committee (COREC: 06/Q1206/165). HBMSCs were isolated and in vitro expanded as previously described (Yang et al. 2001). HDPSCs and HBMSCs were seeded at $2 \times 10^{5}$ cells/well on $35 \mathrm{mg}$ ABM-P-15 and/or ABM particles and were cultured in $500 \mu \mathrm{L}$ of basal media ( $\alpha$-MEM supplemented with $10 \%$ FBS, $1 \%$ penicillin/streptomycin, $2 \mathrm{mM} \mathrm{L}$-glutamine) in an incubator (Binder, Germany) at $37^{\circ} \mathrm{C}$ with $5 \% \mathrm{CO}_{2}$.

Multi-lineage inductive culture of HDPSCs and HBMSCs

For osteogenic culture, HDPSCs and HBMSCs were seeded in 24 well plates $\left(2 \times 10^{4}\right.$ cells/well, P3, $\mathrm{n}=3$ ) and cultured for 3 weeks at $37{ }^{\circ} \mathrm{C}, 5 \% \mathrm{CO}_{2}$ in osteogenic media (basal media supplemented with $10 \mathrm{nM}$ dexamethasone and $100 \mu \mathrm{M}$ L-ascorbic acid 2-phosphate). Basal medium alone was used as the controls for both cell groups. The media were changed 
every 5 days until the cells were harvested for alkaline phosphatase staining.

For adipogenic culture, hDPSCs were seeded onto 24 well plates $\left(2 \times 10^{4}\right.$ cells/well, $\left.\mathrm{P} 3, \mathrm{n}=3\right)$ and cultured for 3 weeks at $37{ }^{\circ} \mathrm{C}$ and $5 \% \mathrm{CO}_{2}$ in adipogenic induction media-basal medium supplemented with $1 \mu \mathrm{M}$ dexamethasone (Sigma), $200 \mu \mathrm{M}$ indomethacin, $0.5 \mathrm{mM}$ isobutyl-methyl xanthine (Sigma) and $10 \mu \mathrm{g} / \mathrm{mL}$ insulin. The basal medium alone was used as the control. The cells were fixed in $10 \%$ neutral buffered formalin (NBF) and were then stained with $0.6 \%$ Oil red O (Sigma) for $15 \mathrm{~min}$ for the identification of lipid droplets.

For chondrogenic culture, HDPSCs and HBMSCs $\left(5 \times 10^{5}\right.$ cells $\left./ \mathrm{mL} ; \mathrm{P} 3 ; \mathrm{n}=3\right)$ were cultured as pellets in the basal media for $48 \mathrm{~h}$ before transferring into chondroinductive media and maintained at $37{ }^{\circ} \mathrm{C}, 5 \%$ $\mathrm{CO}_{2}$ for 3 weeks with media changes every 3 days. Basal medium alone was used as the control group.

The chondroinductive medium was prepared by supplementing the basal media with $0.1 \mu \mathrm{M}$ dexamethasone (Sigma, UK), $10 \mathrm{ng} / \mathrm{mL}$ TGF $\beta 3,50 \mu \mathrm{g} / \mathrm{mL}$ L-ascorbic acid 2-phosphate (Sigma, UK) and $5 \mu \mathrm{g}$ / $\mathrm{mL}$ insulin transferrin selenium (ITS) (Sigma, UK). All cell pellets were, paraffin-embedded, sectioned and stained with Alcian blue/Sirius red for the detection of GAG and collagenous matrix. HDPSCs/ HBMSCs growth on the ABM-P-15 and/or ABM scaffold materials was investigated using a confocal microscope, where a series of $\mathrm{X}-\mathrm{Y}-\mathrm{Z}$ images were taken through the scaffold particles permitting $3 \mathrm{D}$ reconstruction.

Assessment of cells viability and growth on ABMP-15 and ABM scaffolds

At different time points ( $24 \mathrm{~h}, 14$ days and 6 weeks), HDPSCs and HBMSCs cultured on ABM-P-15 and ABM particles were fluorescently labeled with CellTracker ${ }^{\mathrm{TM}}$ Green (CMFDA). Viable cells were imaged under an inverted fluorescent microscope or the Leica confocal microscope (AOBS, UK).

Scanning electron microscopy

After 6 weeks culturing of HDPSCs and HBMSCs on ABM-P-15 and/or ABM scaffolds, the samples were vacuum dried for $16 \mathrm{~h}$ and sputter-coated with gold using an E5000 sputter coater (Polaron, UK) to a thickness of $20 \mathrm{~nm}$ prior being imaged under a Hitachi S-3400 N/Nx scanning electron microscope (Hitachi High Technologies, Japan).

Alkaline phosphatase staining

After fixation in $98 \%$ ethanol, the scaffold constructs were incubated in a solution containing $400 \mu \mathrm{L} 0.25 \%$ Naphthol AS-MX phosphate (Sigma, UK), $2.4 \mathrm{mg}$ of Fast Violet salt in $10 \mathrm{~mL}$ distilled water at $37{ }^{\circ} \mathrm{C}$ for $30 \mathrm{~min}$ (in darkness). Cells expressing alkaline phosphatase enzymes were stained in red colour.

Alkaline phosphatase specific activity (ALPSA) quantification

ALP was quantified in HDPSCs and HBMSCs cultured either as monolayers or on 3D ABM-P-15 and/or ABM scaffolds as described previously ( $\mathrm{Lu}$ et al. 2014; Yang et al. 2003) using a fluorescence spectrophotometer (Fluoroskan ascent, Thermo UK) at $520 \mathrm{~nm}$. Then the ALP activities were normalised to the relevant total DNA content to get the ALPSAs. Statistical analysis was carried out using one-way analysis of variance test with Tukey-Kramer multiple comparisons test. The software used for statistical comparison was GraphPad Instant Software (GraphPad Software, Inc., SanDiego).

In vivo implantations

Previously, we have reported that ABM-P-15 enhanced HBMSCs bone formation in vivo compared to the ABM scaffold alone (Yang et al. 2004). In this study, we investigated the osteogenic capacity of HDPSCs on ABM-P-15 particles to explore its potential for bone tissue engineering under the Home Office project license (40/2953). Briefly, HDPSCs $(130 \mathrm{~mL}$ containing $5 \times 10^{6}$ cells per chamber) were injected into diffusion chambers (Millipore, Bedford, MA) containing ABM-P-15 or ABM alone $(n=4)$, which were implanted intraperitoneally in $\mathrm{MF} 1 \mathrm{Nu} / \mathrm{Nu}$ mice as previously described ( $\mathrm{Lu}$ et al. 2014) for up to 8 weeks.

Alcian blue/Sirius red staining

The samples were partially demineralised in $10 \%$ EDTA ( $\mathrm{pH}$ 7.4) for 2 weeks and embedded in paraffin. 
The sections were stained with Alcian blue $(0.5 \mathrm{~g}$ in $1 \%$ acetic acid in water; Sigma, UK) for $10 \mathrm{~min}$ and then immersed in $1 \%$ aqueous phosphomolybdic acid (Fluka, UK) prior to being stained with $0.3 \%$ picrosirius red (Fluka, UK) for an hour.

Immunofluorescence staining

The sections were firstly incubated in primary antibodies including COL1 (1/50, overnight), OCN (1/50, $1 \mathrm{~h})$ and OPN (1/100) which were followed by incubation for $1 \mathrm{~h}$ in FITC-labelled secondary antibodies (goat anti-mouse for COLI, and/or swine antirabbit for $\mathrm{OCN}$ ). The omit of primary antibody was used as the negative control. The sections were then washed in $1 \times$ PBS with agitation for $2 \mathrm{~h}$ and the nuclei stained with TO-PRO- $3^{\circledR}$ at $1 / 100$ in PBS for 20 min. The images were taken under a confocal microscope.

\section{Results}

Multi-lineage differentiation capacity of HDPSCs compared to HBMSCs in monolayer culture

After 3 weeks of culture, HDPSCs showed much stronger ALP positive staining (red colours. Black arrows) in both osteogenic conditions (Fig. 1a), and basal medium (Fig. 1b) compared to that of HBMSCs in the same culture conditions (Fig. 1c \& d) respectively. Osteogenic inductive culture enhanced the ALP staining in both cell groups compared to the same cells in the basal medium culture. After 3 weeks of culture in adipogenic inductive media, Oil red $\mathrm{O}$ staining showed that adipogenic culture condition induced lipid droplet formation in both HDPSCs (Fig. 1e) and HBMSCs (Fig. 1g) groups compare to the same cells in basal medium culture condition (Fig. 1f, h) respectively. However, there was no notable difference in staining between HDPSCs and HBMSCs. After 3 weeks of pellet culture in chondrogenic media, both HDPSCs (Fig. 1i) and HBMSCs (Fig. 1k) samples were stained strongly positive for Alcian blue staining probably reflecting sulphate glycosaminoglycans (GAGs: blue colours) with the sparse presence of collagen (red colours) which was indicated when the pellets were stained up by Sirius red (red colour). There were some chondrocyte-like cells within the pellets and somewhere, the chondrocyte-like cells aligned in column-oriented in certain directions (Fig. 1i, k and the inserts: black arrows). In comparison, both cells in the basal medium culture condition appeared to lack of blue staining (Fig. $1 \mathrm{j}$ and $\mathrm{l}$ ).

HDPSCs/HBMSCs viability and spreading on ABM-P-15 and ABM scaffolds

After $24 \mathrm{~h}$ of cell seeding $(\mathrm{n}=3)$, CMFDA fluorescent labelling showed that the majority of both cells on ABM-P-15 and ABM alone are viable. HDPSCs (Fig. 2a) and HBMSCs (Fig. 2c) were observed to have more cell attachment and better spreading on the scaffolds in ABM-P-15 groups in comparison to that of the ABM alone group (Fig. $2 b$ and $d$ ), where the most of the particles only have a few cells attached. After 14 days of culture in basal media, HDPSC showed better cell spreading, and proliferation (cell density), cell bridging formation on ABM-P-15 (Fig. 2e) compare to HBMSCs on the ABM-P-15 scaffolds (Fig. 2g). Both cells' growth on ABM alone was shown in Fig. $2 \mathrm{f}$ and h. After 6 weeks in culture $(n=3)$ in basal media, Live/dead labelling and confocal images showed that extensive HDPSCs on both ABM-P-15 and ABM scaffolds after 6 weeks of culture (Fig. $2 \mathrm{i}$ and j). For both scaffold types, HDPSCs were seen to be spread across scaffold particles to form cell bridges. The clustering of the scaffolds particles was observed in the case of the ABM-P-15 scaffolds (Fig. 2i) in comparison with the same cells on ABM scaffolds (Fig. 2j). However, there was much less HBMSCs growth on both scaffold types compared to the HDPSCs. Similarly, it can be seen that P-15 enhanced the growth of HBMSCs on ABM-P-15 (Fig. 2k) in comparison to the same cells on the ABM alone scaffolds (Fig. 21).

SEM imaging to show cells growth and matrix deposition on ABM-P-15 and ABM scaffolds

After 6 weeks of culture in basal medium, Scanning electron micrographs showed that HDPSCs and HBMSCs had formed clusters, presumably related to cell bridging and matrix deposition on ABM-P-15 (Fig. 3a and c) and ABM scaffolds (Fig. 3b and d). The cells on the scaffolds appeared to have formed a thick sheet-like layer encasing the scaffold particles. This was observed for both cell types and for ABM-P- 


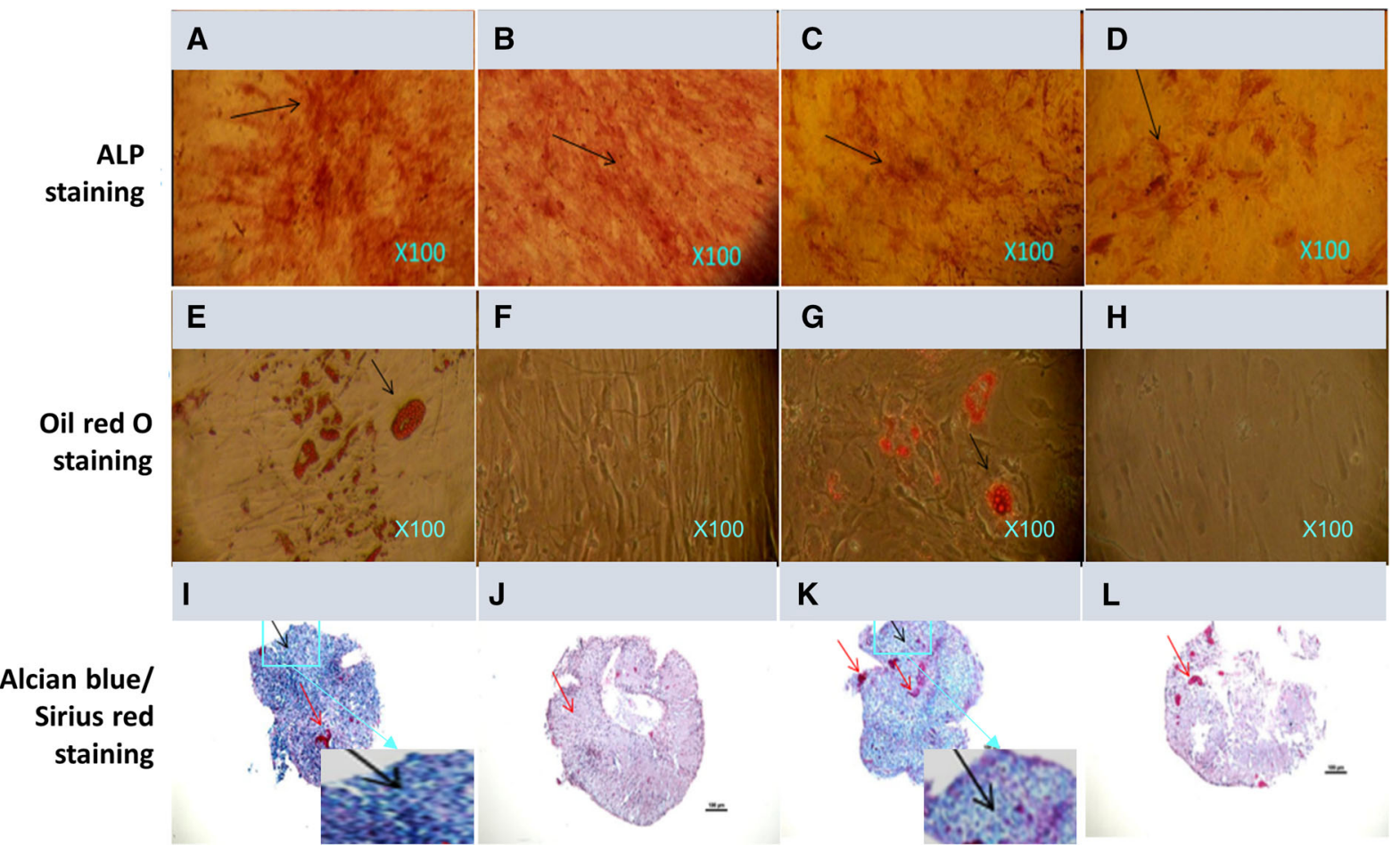

Fig. 1 Histological staining of HDPSCs $(\mathbf{a}, \mathbf{b}, \mathbf{e}, \mathbf{f}, \mathbf{i}, \mathbf{j})$ and HBMSCs (c, d, g, h, k, l) after 3 weeks of culture under osteogenic (a, c), adipogenic (e, g), chondrogenic (i,

15 and $\mathrm{ABM}$ alone scaffolds, respectively. Figure $3 \mathrm{e}$ and $\mathrm{f}$ showed the ABM-P-15 and ABM scaffolds without cells.

ALP staining and ALP Specific activity of HDPSCs and HBMSCs on ABM-P-15 and/ or ABM particles

After 6 weeks of culture in basal medium, ABM-P-15 groups for both HDPSCs and HBMSCs showed enhanced ALP staining compared to that of the same cell types on ABM scaffolds (Fig. 4). There was no visible difference between HDPSCs (Fig. 4a) and HBMSCs groups on the ABM-P-15 scaffolds (Fig. 4c). For the ABM alone groups, the HBMSCs group (Fig. 4d) showed stronger ALP stain than that of the HDPSCs group (Fig. 4b). However, these were not a significant difference in the ALPSA $(\mathrm{P}>0.05)$. Biochemical quantitative assays confirmed that HDPSCs cultured on ABM-P-15 scaffolds had the highest ALPSA compared to HDPSCs on ABM alone scaffolds $(200 \%$ increase $) \quad(\mathrm{P}<0.001$, Fig. $4 \mathrm{e})$. k) inductions and basal conditions (b, d, f, h, j, l). a-d ALP staining; $\mathbf{e}-\mathbf{h}$ Oil red $\mathrm{O}$ staining; $\mathbf{i}-\mathbf{l})$ Alcian Blue/Sirius red staining. Scale bars-100 $\mu \mathrm{m}$

Similarly, HBMSCs cultured on ABM-P-15 scaffolds also had significantly higher ALPSA compared to the cells cultured on ABM scaffolds alone (100\% increase) $(\mathrm{P}<0.05$, Fig. 4e). The mean of ALPSA of HDPSCs was $30 \%$ higher than that of HBMSCs on the ABM-P-15 group. However, there was no statistic difference in the ALPSA between the two cell types $(\mathrm{P}>0.05)$.

Sirius red staining and Birefringence images to show the fibrous collagen matrix present in HDPSC-ABM-P-15 and/or ABM scaffold construct in vivo

After 8 weeks of in vivo implantation $(n=4)$, three out of four HDPSCs-ABM-P-15 constructs showed positive staining for Sirius red (Fig. 5a). In comparison, only one out of four HDPSCs-ABM constructs showed positive stinging for Sirius red (Fig. 5b). In the negative control groups, ABM-P-15 and ABM scaffolds without cells, there was no indication of the presence of cells or tissues within the constructs. 

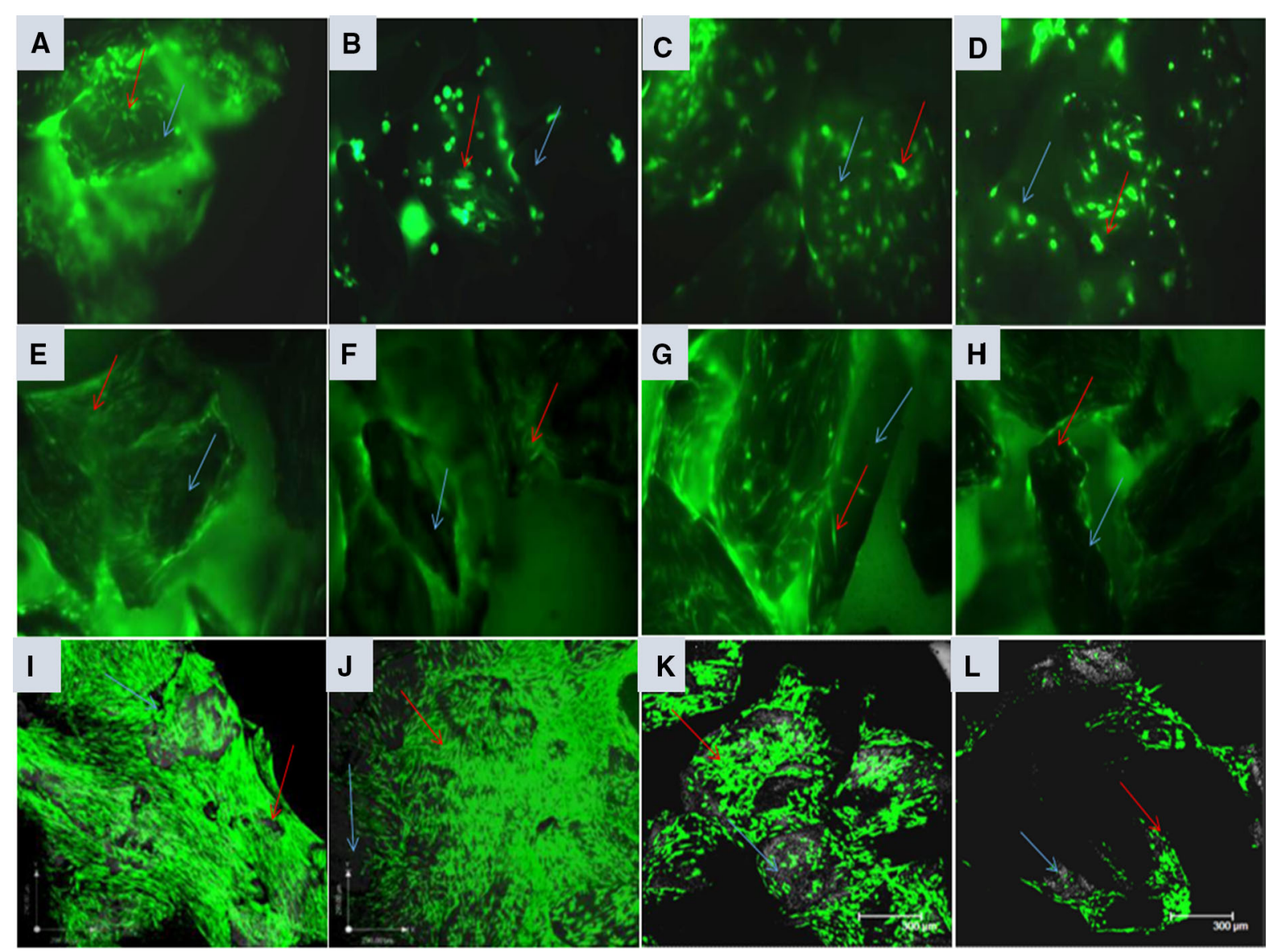

Fig. 2 Fluorescent micrographs from an inverted fluorescent microscope $(\mathbf{a}-\mathbf{h})$ and confocal microscope (i-l) of CMFDA labelled HDPSCs $(\mathbf{a}, \mathbf{b}, \mathbf{e}, \mathbf{f}, \mathbf{i}, \mathbf{j})$ and HBMSCs $(\mathbf{c}, \mathbf{d}, \mathbf{g}, \mathbf{h}, \mathbf{k}$, l) after $24 \mathrm{~h}(\mathbf{a}-\mathbf{d}), 4$ days $(\mathbf{e}-\mathbf{h})$ and 6 weeks $(\mathbf{i}-\mathbf{l})$ of in vitro

Under polarized light microscopy, the Sirius redstained collagen matrix exhibited birefringence, and the fibres appeared green/red/orange in colour (Fig. 5c and d). A denser and more highly organised collagen matrix was observed in the HDPSCs-ABM-P-15 constructs (Fig. 5c) compared to that in the HDPSCs-ABM constructs (Fig. 5d).

Immuno fluorescent characterisation of the extracellular matrix of HDPSCs-ABM-P-15 and/or HDPSCs-ABM scaffolds constructs in vivo

After 8 weeks of in vivo implantation, immunofluorescent staining showed that HDPSCs-ABM-P-15 groups appeared to have more and stronger positive stains (green colour, red arrows) for COL1 and OCN within the cells and extracellular matrixes, the cultures on ABM-P-15 (a, e, i, c, g, k) and ABM scaffolds (b, f, $\mathbf{j}, \mathbf{d}, \mathbf{h}, \mathbf{l})(\mathrm{n}=3)$. Red arrows: viable cells; blue arrows: ABM-P15/ABM particle. Magnifications: $\times 100$

collagen matrixes were dense and organised around individual ABM-P-15 scaffold (Fig. 6a and b) compared to that of ABM alone group (Fig. 6e and f) respectively, in which the matrixes were less organised between the scaffold particles while the most of organised matrixes were observed around the peripheral layer. In comparison, there were less staining for OCN than COL1 within the same group. The nuclei were stained as blue colour, and the ABM particles were shown as the grey colour (blue arrows). The HDPSCs on both ABM-P-15 (Fig. 6c) and ABM scaffold groups showed strong positive stains for OPN (Fig. 6g). There was no clear difference between the two groups. There were not positive stains in the negative control groups (without primary antibodies) on ABM-P-15 (Fig. 6d) and ABM alone (Fig. 6h). 
Fig. 3 Scanning electron microscopy images of HDPSCs $(\mathbf{a}, \mathbf{b})$ and HBMSCs (c, b) after 6 weeks of in vitro culture on ABM-P-15 (a, c) and $\mathrm{ABM}(\mathbf{b}, \mathbf{d})$, as well as both scaffolds without cells $(\mathbf{e}, \mathbf{f})$. HDPSCs and HBMSCs on both ABM -P-15 and ABM scaffolds were observed to deposit matrix (red arrows) around the scaffolds particles (blue arrows)
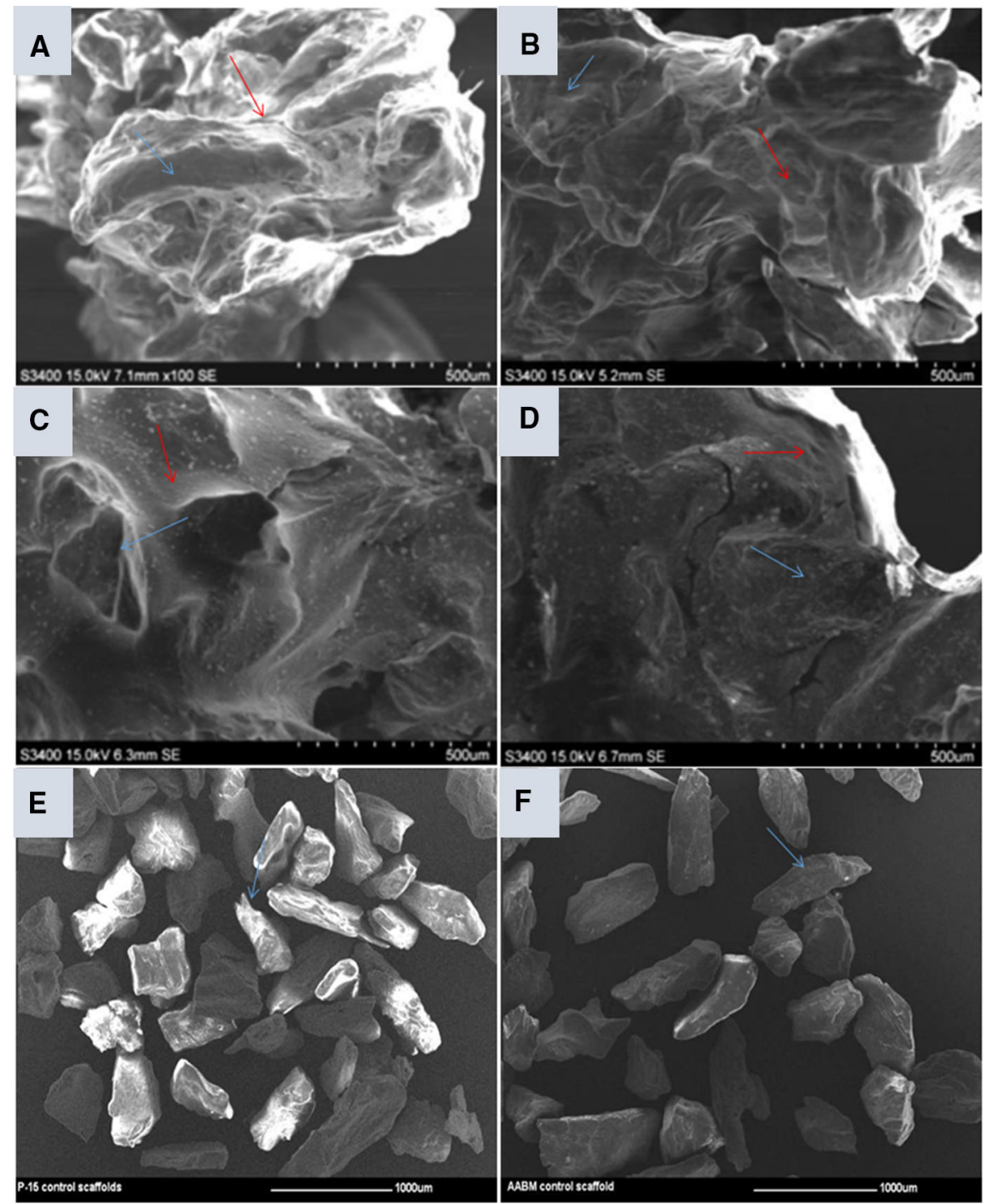

\section{Discussion}

Translational research on bone tissue engineering aims to develop cell-based bone graft material that could be employed as a substitute for the traditional grafts for bone augmentation. However, one of the current challenges in this field is the identification of an ideal combination of stem cells, scaffold material and growth factors that could be used for faster repair/ regeneration of damaged bone (Panetta et al. 2009) and/or improve the implant-bone osseointegration (Jayesh and Dhinakarsamy 2015; Ting et al. 2016). In this study, the effect of ABM-P-15 on HDPSCs osteogenesis was investigated both in vitro and in vivo compared with HBMSCs with the aims of developing novel stem cell-biomaterials combinations for enhancing bone tissue repair/regeneration efficacy and improve the implant-bone interface for clinical application.

Although HBMSCs has been considered as one of the most popular stem cell sources (Squillaro et al. 2016; Yoshii et al. 2009), however, due to the limitation of getting a good quality of HBMSC and considerable very long doubling time of this cell population, resulting in a slow or low efficacy bone formation procedure. In fact, for clinical therapy, the speed for bone formation may be more important than the amount of bone formation itself (e.g. taking longer 


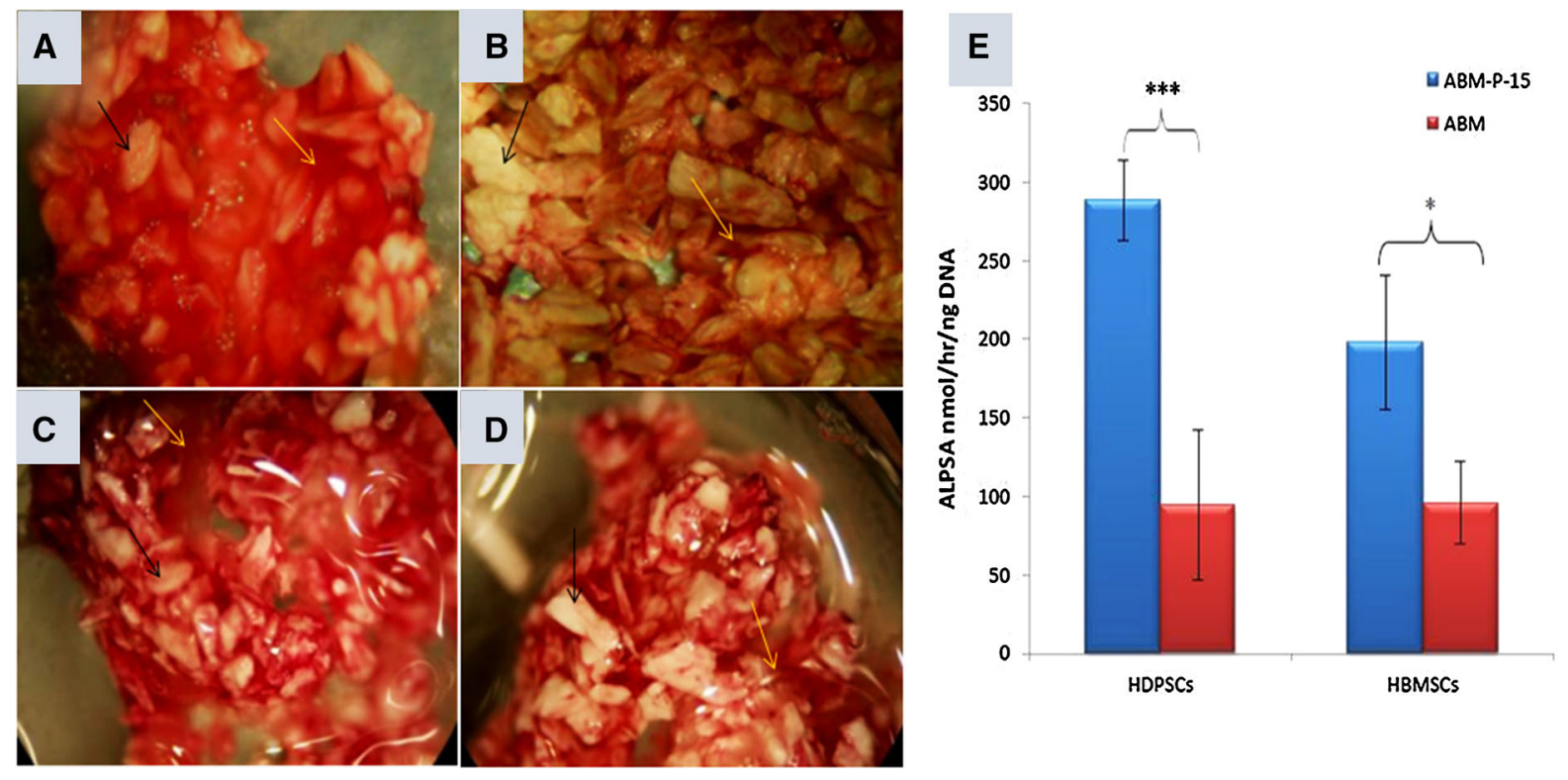

Fig. 4 ALP staining (a-d) and quantification of ALP specific activities (e) for HDPSCs (a, b) and HBMSCs (c, d) after 6 weeks of culture on ABM-P-15 (a, c) and ABM $(\mathbf{b}, \mathbf{d})$ scaffolds $(\mathrm{n}=3)$. $* P<0.05 ; * * * P<0.001$

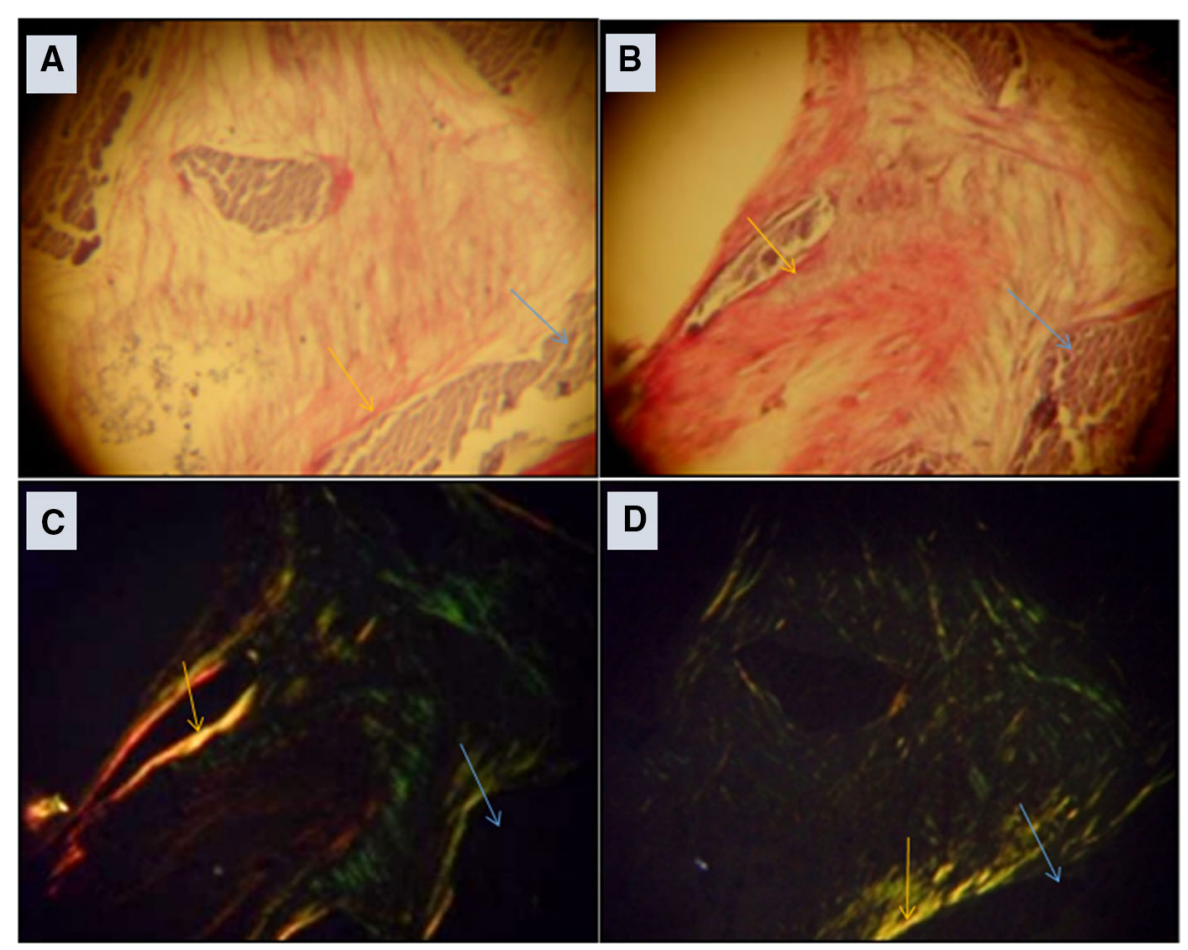

Fig. 5 Alcian blue/Sirius red staining $(\mathbf{a}, \mathbf{b})$ and birefringence (c, d) of the fibrous collagenous matrix present in HDPSCABM-P-15 (a, c) and/or HDPSC-ABM (b, d) scaffold constructs after 8 weeks of in vivo implantation in a diffusion chamber model. Yellow arrows: collagen matrix formation (red or bright colour) and orientation; Blue arrows: ABM particles. Magnifications: $\times 200$ 

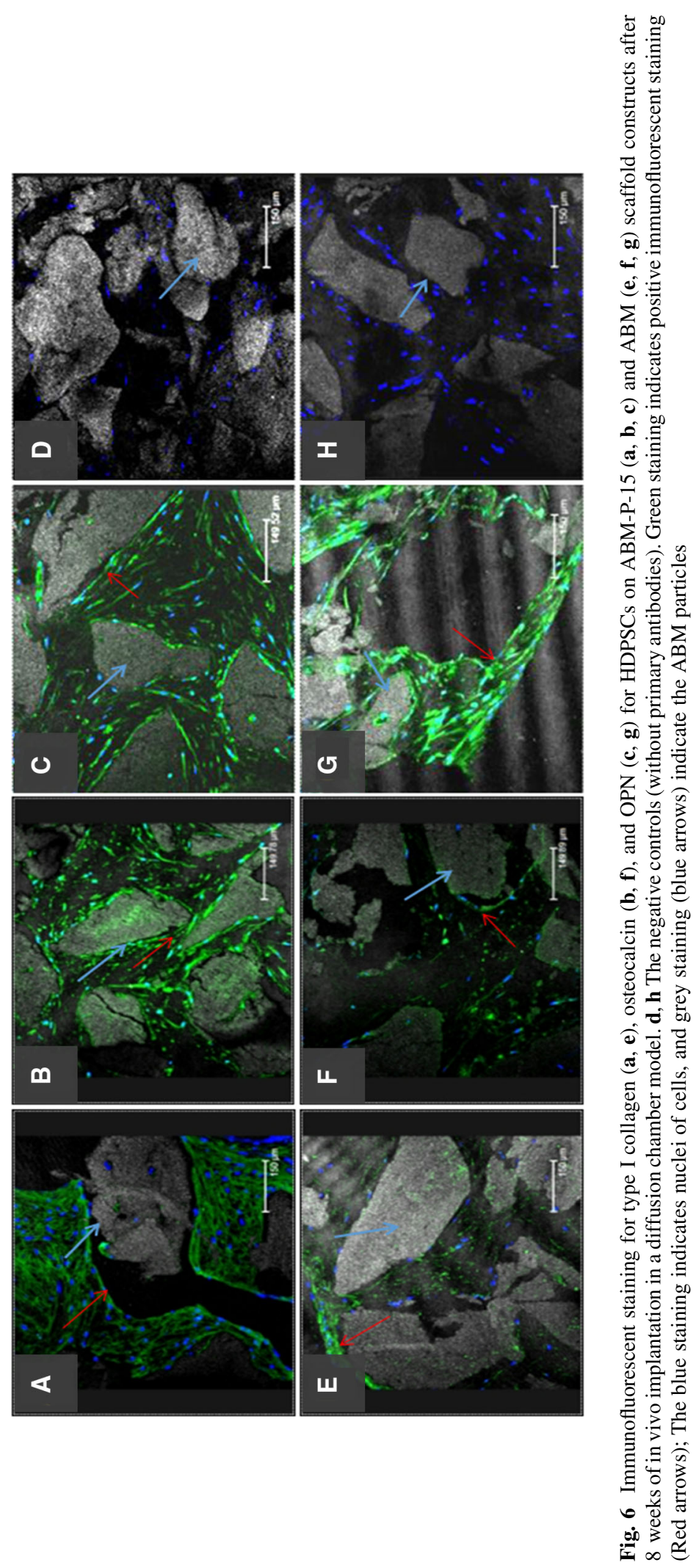
time). Therefore, researchers are looking for different alternatives for bone tissue regeneration. A number of studies showed that HDPSCs from dental pulp tissue is highly proliferative, short doubling time, multipotency, in particular with high osteogenic potential, which makes these cells alternative candidates for bone tissue regeneration (El-Gendy et al. 2015; Yamada et al. 2019). In this study, both HDPSCs and HBMSCs showed low adipogenic and chondrogenic potential but with some osteogenic potential in basal medium culture conditions. However, when cultured in inductive media, both HDPSCs and HBMSCs showed the enhanced capacity for their osteogenesis, adipogenesis, and chondrogenesis. HDPSCs group showed stronger stain for Alcian blue, which indicated more cartilage proteoglycans (Saha et al. 2013; Ullah et al. 2012) were formed in this group compared to that of HBMSCs group in basal. Similarly, the HDPSCs group showed stronger ALP positive staining than that of HBMSCs group in osteogenic inductive culture condition. These results were in agreement with the literature in supporting HDPSCs as an alternative stem cell source for bone tissue engineering (El-Gendy et al. 2013; El-Gendy et al. 2015).

Although in this study, the difference in the number of cells attached on both ABM scaffolds was not quantified, morphological observations appeared that P-15 increased the cell-binding after $24 \mathrm{~h}$ of seeding and enhanced the cell proliferation/cell bridge formations after 14 days of seeding for both HDPSCs and HBMSCs onto ABM-P-15 particles compared to ABM scaffolds alone, which was consistent with our previous study on HBMSCs (Yang et al. 2004) and the work of others on different cell populations (Bhatnagar et al. 1999b; Emecen et al. 2009; Lallier et al. 2003). Following long term culture (6 weeks in the basal medium in vitro), interestingly it was observed that extensive viable HDPSCs were growing on both ABM-P-15 and ABM alone scaffolds. In comparison, there were much fewer HBMSCs on both groups although there was a sign of more HBMSCs on the ABM-P-15 scaffolds than that on ABM alone scaffolds. These may be due to the higher proliferation rate and lower population doubling time for HDPSCs (Eslaminejad et al. 2010; Pisciotta et al. 2015) compared to that of HBMSCs. Bhatnagar et al. (Bhatnagar et al. 1999c) showed that P-15 stimulated ECM synthesis. In this study, both HDPSCs or
HBMSCs cultured on ABM-P-15 appeared to deposit well organised ECM around the individual scaffold particles after 14 days of seeding, which holds the separate ABM particles together in clusters (Yang et al. 2004). In contrast, the cells on ABM alone were observed to be concentrated on individual scaffold particles and formed fewer cell bridges with the neighbouring scaffold particles. The enhanced cell bridge formation in cells cultured on ABM-P-15 might be attributed to the development of traditional force by the cells, which is important for the organisation of the matrix and tissue morphogenesis (Bhatnagar et al. 1999a; Schwartz 2010). This study, however, has not measured difference in the tractional force imparted by the cells cultured in the presence of ABM-P-15 and ABM scaffolds and also no characterisation of the deposited matrix by HDPSCs/HBMSCs on ABM-P15 and ABM scaffolds.

$\mathrm{P}-15$ functions as surrogate collagen in enhancing osteogenic differentiation of the adhered cells, by the up-regulation in growth factors expression such as bone morphogenetic proteins (BMPs)-2, 6 and 7 . Enhanced expression of BMP-2, 6 and 7 are documented in influencing the cells' osteogenic differentiation in an autocrine or paracrine manner (Bandyopadhyay et al. 2006; Li and Cao 2006; Nguyen et al. 2003) and are involved in the synthesis of collagen, OCN and other extracellular matrix proteins (Bhatnagar et al. 1999a, b; Locklin et al. 1999; Warren et al. 2001). ALP is a widely studied pre-osteoblastic marker that is expressed during the end of osteoblast proliferation (Lian and Stein 1995; Lu et al. 2014; Mendes et al. 2004). Immobilised P-15 on ABM scaffolds were observed to up-regulate the ALP expression of human dermal fibroblasts, HBMSCs and periodontal ligament fibroblasts (Qian and Bhatnagar 1996; Yang et al. 2004; Yuan et al. 2007) and this effect has been correlated with the increase in BMP-2 expression (Spinella-Jaegle et al. 2001). The up-regulation of ALP is essential for matrix mineralisation as it catalyses the hydrolysis of phosphomonoesters at alkaline $\mathrm{pH}$ (Bellows et al. 1991; Gillette and Nielsen-Preiss 2004). In this study, both HDPSCs and HBMSCs group showed much stronger ALP positive staining compared to the same cell types growth on the ABM scaffold alone after 6 weeks of in vitro culture in basal medium. Quantitative biochemical assays confirmed that the ALPSA of HDPSCs on ABM-P-15 group is $200 \%$ increase 
compared with that of the same cells on ABM along group. There were $100 \%$ increasing in ALPSA in HBMSCs cultured on ABM-P-15 group than that of the same cells on ABM alone group. The ALPSA of HDPSCs on ABM-P-15 group was higher than that of HBMSCs on ABM-P-15 group (32\%), which was similar to the results of Kwon et al. (2015) (Kwon et al. 2015). These results may indicate that the response of tested HDPSCs to ABM-P-15 was more sensitive than the tested HBMSCs. However, there was no statistic difference in the ALPSA between the two cell types $(\mathrm{P}>0.05)$.

The diffusion chamber model has been used for decades to test the tissue regenerative strategy (Ashton et al. 1980; Gundle et al. 1995; Howard et al. 2002; Nawata et al. 2005; Partridge et al. 2002; Yang et al. 2003, 2004). It can be implanted intraperitoneally in mouse or rat and provide a permissive physiological environment in supporting stem cell growth, function and tissue regeneration in vivo. The enclosed system allows the exchange of nutrients, oxygen and waste across the membrane filters but prevents the entry of host cells and tissue into the constructs (Horner et al. 2008; Lu et al. 2014). Previously, we have shown that ABM-P-15 promoted HBMSCs forming bone matrix after 6 weeks implantation (Yang et al. 2004). Similarly in this study, after 8 weeks in vivo implantation in MF1 Nu/Nu mice, the ABM-P-15 group showed highly organised collagen matrix formation within the diffusion chamber, which indicates that ABM-P-15 enhanced HDPSC bone formation compared to that of ABM alone group. These results were supported by enhanced immune fluorescent staining for COL-1 and OCN, in the ABM-P-15 group, confirming terminal differentiation of the HDPSCs. In comparison to the normal light microscope, the use of polarised microscopy for the identification of collagen orientation is preferred as it increases the specificity and resolution for the observation of the thin collagen fibres which are not detectable under normal microscopy (Junqueira et al. 1979; Rich and Whittaker 2005; Spiesz et al. 2011; Traini et al. 2006).

In the native microenvironment, the cells are under constant interaction with the extracellular matrix through the integrin receptors present in the cell membrane (De Franceschi et al. 2015; Schwartz 2010). Integrin receptors, not only function as cell adhesion molecules for the anchorage of the cells to the matrix but are also involved in the transmission of bidirectional signals across the cell, and the matrix thereby helps in the regulation of the cell proliferation, migration and differentiation (Carinci et al. 2004; Emsley et al. 2000; Jokinen et al. 2004). Similar to the native collagen fibre, the $\mathrm{P}-15$ receptors have also been identified to interact with the $\alpha 2 \beta 1$ integrin receptors of the cells to enhance the attachment and differentiation in different cell types. The biomimetic scaffolds employed in this study mimics the autologous bone structure, where the surfaces of ABM particles are immobilised with $\mathrm{P}-15$ peptides, which are molecules of the cell recognition sequence of the type 1 collagen (Bhatnagar et al. 1998; Murray et al. 2003; Pountos et al. 2016; Xu et al. 2000; Yu et al. 2011) and can initiate the cascade events for bone formation. A number of studies have also shown that ABM-P-15 enhances osteogenic differentiation and bone matrix formation using different cell types (Lindley et al. 2010; Matos et al. 2011; Vastardis et al. 2005; Yang et al. 2004; Yuan et al. 2007). The combination of ABM with $\mathrm{P}-15$ and autologous HDPSCs is to mimic autologous bone graft.

\section{Conclusion}

The current study provided direct evidence that HDPSCs contain multipotent stem cells that have a high proliferation rate and osteogenic potential compared to HBMSCs. ABM-P-15 promoted HDPSCs osteogenic differentiation and bone matrix formation both in vitro and in vivo, which indicated the potential of combining HDPSC and ABM-P15 for enhancing bone tissue engineering efficacy to meet the clinical reality in tackling fracture non-union, critical bone defect and/or implant loosening in orthopaedics and dentistry.

Funding YM's Ph. D. programme was partially funded by Overseas Research Scholarships (ORS) and Cerapedics Inc. JZ and XY were partially sponsored by UK-China Science Bridge Award via Changzhou Science and Technology Bureau (102178), Changzhou Kanghui Medical Innovation Co. Ltd. JZ was partially funded by the National Natural Science Foundation of China (No. 81500890) and the "Group-type" Special Support Project for Education Talents in Universities (G619080438, 4SG19002G, 4SG19044G, 4SG19214G, 4SG19057G). YM acknowledges Emerita Professor Jennifer Kirkham for her supervision, support and advice during her $\mathrm{Ph}$. D. study. 
Availability of data and materials Not applicable.

Code availability Not applicable.

\section{Complicance with ethical standards}

Conflicts of interest Dr. Xuebin Yang declares that he is bound by confidentiality agreements that prevent him from disclosing his competing interests in this work. He has no competing interests over the last 5 years. All other authors have no competing interests.

Ethical approval Teeth were extracted at Leeds School of Dentistry with patients' informed consent and ethical approval (LREC 07/H1306/93). Human bone marrow samples were obtained at Leeds General Infirmary and Chapel Allerton Hospital with patients' informed consent and ethical approval by the NHS local ethical committee (COREC: 06/Q1206/165). The in vivo work include the use of $\mathrm{Nu} / \mathrm{Nu}$ mice was covered by Home Office project license (40/2953), which has been approved by the Animal Welfare and Ethical Review Committee (A311: University of Leeds, Leeds, UK).

Consent to participate Not applicable.

Consent for publication Not applicable.

Open Access This article is licensed under a Creative Commons Attribution 4.0 International License, which permits use, sharing, adaptation, distribution and reproduction in any medium or format, as long as you give appropriate credit to the original author(s) and the source, provide a link to the Creative Commons licence, and indicate if changes were made. The images or other third party material in this article are included in the article's Creative Commons licence, unless indicated otherwise in a credit line to the material. If material is not included in the article's Creative Commons licence and your intended use is not permitted by statutory regulation or exceeds the permitted use, you will need to obtain permission directly from the copyright holder. To view a copy of this licence, visit http://creativecommons.org/licenses/by/4.0/.

\section{References}

Abdulghani S, Mitchell GR (2019) Biomaterials for in situ tissue regeneration: a review. Biomolecules. https://doi.org/10. 3390/biom9110750

Ashton BA, Allen TD, Howlett CR, Eaglesom CC, Hattori A, Owen M (1980) Formation of bone and cartilage by marrow stromal cells in diffusion chambers in vivo. Clin Orthop Relat Res 151:294-307

Bandyopadhyay A, Tsuji K, Cox K, Harfe BD, Rosen V, Tabin CJ (2006) Genetic analysis of the roles of BMP2, BMP4, and BMP7 in limb patterning and skeletogenesis. PLoS Genet 2:e216

Barboza EP, de Souza RO, Caúla AL, Neto LG, de Oliveira Caúla F, Duarte MEL (2002) Bone regeneration of localized chronic alveolar defects utilizing cell binding peptide associated with anorganic bovine-derived bone mineral: a clinical and histological study. J Periodontol 73:1153-1159

Bellows C, Aubin J, Heersche J (1991) Initiation and progression of mineralization of bone nodules formed in vitro: the role of alkaline phosphatase and organic phosphate. Bone Mineral 14:27-40

Bhatnagar RS, Qian JJ, Gough CA (1997) The role in cell binding of a $\beta$-bend within the triple helical region in collagen $\alpha 1$ (I) chain: structural and biological evidence for conformational tautomerism on fiber surface. J Bio Mol Struct Dyn 14:547-560

Bhatnagar R, Wedrychowska A, Smith N (1998) Construction of biomimetic environments with a synthetic peptide analogue of collagen. Materials Research Society, pp 43-54

Bhatnagar R, Qian J, Wedrychowska A, Dixon E, Smith N (1999a) Biomimetic habitats for cells: ordered matrix deposition and differentiation in gingival fibroblasts cultured on hydroxyapatite coated with a collagen analogue. Cells Mater 9:93-104

Bhatnagar R, Qian J, Wedrychowska A, Sadeghi M, Wu Y, Smith N (1999b) Design of biomimetic habitats for tissue engineering with P-15, a synthetic peptide analogue of collagen. Tissue Eng 5:53

Bhatnagar RS, Gough CA, Qian JJ, Shattuck M (1999c) Fine structure of collagen: molecular mechanisms of the interactions of collagen. Proc Indian Acad Sci 111:301

Carinci F et al (2004) P-15 cell-binding domain derived from collagen: analysis of MG63 osteoblastic-cell response by means of a microarray technology. J Periodontol 75:66-83

Chandran S, John A (2019) Osseointegration of osteoporotic bone implants: role of stem cells, Silica and Strontium-a concise review. J Clin Orthop Trauma 10:S32-s36. https:// doi.org/10.1016/j.jcot.2018.08.003

Connolly J, Guse R, Lippiello L, Dehne R (1989) Development of an osteogenic bone-marrow preparation. J Bone Jt Surg 71:684

Cui L, Xu S, Ma D, Gao J, Liu Y, Yue J, Wu B (2014) The role of integrin-alpha5 in the proliferation and odontogenic differentiation of human dental pulp stem cells. J Endod. 40:235-240. https://doi.org/10.1016/j.joen.2013.08.011

De Franceschi N, Hamidi H, Alanko J, Sahgal P, Ivaska J (2015) Integrin traffic-the update. J Cell Sci 128:839-852. https://doi.org/10.1242/jcs.161653

El-Gendy R, Yang XB, Newby PJ, Boccaccini AR, Kirkham J (2013) Osteogenic differentiation of human dental pulp stromal cells on 45S5 Bioglass(R) based scaffolds in vitro and in vivo. Tissue Eng Part A 19:707-715. https://doi.org/ 10.1089/ten.TEA.2012.0112

El-Gendy R, Kirkham J, Newby PJ, Mohanram Y, Boccaccini AR, Yang XB (2015) Investigating the Vascularization of Tissue-Engineered Bone Constructs Using Dental Pulp Cells and 45S5 Bioglass(R) Scaffolds. Tissue Eng Part A 21:2034-2043. https://doi.org/10.1089/ten.tea.2014.0485

Emecen P, Akman AC, Hakki SS, Hakki EE, Demiralp B, Tozum TF, Nohutcu RM (2009) ABM/P-15 modulates proliferation and mRNA synthesis of growth factors of periodontal ligament cells. Acta Odontol Scand 67:65-73. https://doi.org/10.1080/00016350802555525 
Emsley J, Knight CG, Farndale RW, Barnes MJ, Liddington RC (2000) Structural basis of collagen recognition by integrin [alpha] 2 [beta] 1. Cell 101:47-56

Eslaminejad B, Vahabi S, Shariati M, Nazarian H (2010) In vitro growth and characterization of stem cells from human dental pulp of deciduos versus permanent teeth. J Dent $7: 185$

Garcia-Sanchez D, Fernandez D, Rodriguez-Rey JC, PerezCampo FM (2019) Enhancing survival, engraftment, and osteogenic potential of mesenchymal stem cells. World J Stem Cells. 11:748-763. https://doi.org/10.4252/wjsc.v11. i10.748

Gillette JM, Nielsen-Preiss SM (2004) The role of annexin 2 in osteoblastic mineralization. J Cell Sci 117:441

Gothard D, Dawson JI, Oreffo RO (2013) Assessing the potential of colony morphology for dissecting the CFU-F population from human bone marrow stromal cells. Cell Tissue Res 352:237-247. https://doi.org/10.1007/s00441013-1564-3

Gronthos S, Mankani M, Brahim J, Robey PG, Shi S (2000) Postnatal human dental pulp stem cells (DPSCs) in vitro and in vivo. Proc Natl Acad Sci USA 97:13625-13630. https://doi.org/10.1073/pnas.240309797

Gundle R, Joyner CJ, Triffitt JT (1995) Human bone tissue formation in diffusion chamber culture in vivo by bonederived cells and marrow stromal fibroblastic cells. Bone 16:597-601

Hofmann S et al (2007) Control of in vitro tissue-engineered bone-like structures using human mesenchymal stem cells and porous silk scaffolds. Biomaterials 28:1152-1162

Horner EA, Kirkham J, Yang XB (2008) Animal models. In: Polak $\mathbf{J}$ (ed) Advances in tissue engineering. Imperial College Press, London

Howard D et al (2002) Immunoselection and adenoviral genetic modulation of human osteoprogenitors: in vivo bone formation on PLA scaffold. Biochem Biophys Res Commun 299:208-215

Iaquinta MR et al (2019) Innovative biomaterials for bone regrowth. Int J Mol Sci. https://doi.org/10.3390/ ijms 20030618

Jayesh RS, Dhinakarsamy V (2015) Osseointegration. J Pharm Bioallied Sci 7:S226-229. https://doi.org/10.4103/09757406.155917

Jokinen J et al (2004) Integrin-mediated cell adhesion to type I collagen fibrils. J Biol Chem 279:31956

Jones E, Schafer R (2015) Where is the common ground between bone marrow mesenchymal stem/stromal cells from different donors and species? Stem Cell Res Ther 6:143. https://doi.org/10.1186/s13287-015-0144-8

Junqueira LCU, Bignolas G, Brentani R (1979) Picrosirius staining plus polarization microscopy, a specific method for collagen detection in tissue sections. Histochem $\mathrm{J}$ 11:447-455

Kawashima N, Okiji T (2016) Odontoblasts: specialized hardtissue-forming cells in the dentin-pulp complex. Congenit Anom (Kyoto). https://doi.org/10.1111/cga.12169

Kern S, Eichler H, Stoeve J, Klüter H, Bieback K (2006) Comparative Analysis of Mesenchymal Stem Cells from Bone Marrow. Umbilical Cord Blood, or Adipose Tissue STEM CELLS 24:1294-1301. https://doi.org/10.1634/ stemcells.2005-0342
Kwon DY et al (2015) A computer-designed scaffold for bone regeneration within cranial defect using human dental pulp stem cells Sci Rep 5:12721. https://doi.org/10.1038/ srep12721

Lallier TE, Palaiologou AA, Yukna RA, Layman DL (2003) The putative collagen-binding peptide $\mathrm{P}-15$ promotes fibroblast attachment to root shavings but not hydroxyapatite. J Periodontol 74:458-467. https://doi.org/10.1902/jop.2003. 74.4.458

Ledesma-Martinez E, Mendoza-Nunez VM, Santiago-Osorio E (2016) Mesenchymal stem cells derived from dental pulp: a review. Stem Cells Int 2016:4709572. https://doi.org/10. $1155 / 2016 / 4709572$

Li X, Cao X (2006) BMP signaling and skeletogenesis. Ann N Y Acad Sci 1068:26-40

Lian J, Stein G (1995) Development of the osteoblast phenotype: molecular mechanism mediating osteoblast growth and differentiation. Iowa Orthop J 15:118-140

Lindley EM, Guerra FA, T Krauser J, Matos SM, Burger EL, Patel VV (2010) Small peptide (P 15) bone substitute efficacy in a rabbit cancellous bone model. J Biomed Mater Res B Appl Biomater 94:463-468

Liu Y, Rath B, Tingart M, Eschweiler J (2019) Role of implants surface modification in osseointegration: a systematic review. J Biomed Materials Research Part A. https://doi. org/10.1002/jbm.a.36829

Locklin RM, Oreffo ROC, Triffitt JT (1999) Effects of TGF [beta] and bFGF on the differentiation of human bone marrow stromal fibroblasts. Cell Biol Int 23:185-194

Lu W et al (2014) Bone tissue engineering by using a combination of polymer/Bioglass composites with human adipose-derived stem cells. Cell Tissue Res 356:97-107. https://doi.org/10.1007/s00441-013-1770-z

Mardas N, Stavropoulos A, Karring T (2008) Calvarial bone regeneration by a combination of natural anorganic bovine derived hydroxyapatite matrix coupled with a synthetic cell binding peptide (PepGen ${ }^{\mathrm{TM}}$ ): an experimental study in rats. Clin Oral Implant Res 19:1010-1015

Matos S, Guerra F, Krauser JT, Figueiredo H, Marcelino JP, Sanz M (2011) Evaluation of an anorganic bovine derived mineral with $\mathrm{P} 15$ hydrogel bone graft: preliminary study in a rabbit cranial bone model. Clin Oral Implant Res 23:698-705. https://doi.org/10.1111/j.1600-0501.2011. 02179.x

Mendes S, Tibbe J, Veenhof M, Both S, Oner F, Van Blitterswijk C, De Bruijn J (2004) Relation between in vitro and in vivo osteogenic potential of cultured human bone marrow stromal cells. J Mater Sci 15:1123-1128

Mortada I, Mortada R (2018) Dental pulp stem cells and osteogenesis: an update. Cytotechnology 70:1479-1486. https://doi.org/10.1007/s10616-018-0225-5

Murray RK, Granner DK, Mayes PA, Rodwell VW (2003) Harper's Illustrated Biochemistry, 26th edn. Lange Medical Books/McGraw-Hill, New York

Muschler GF, Nitto H, Boehm CA, Easley KA (2001) Age and gender related changes in the cellularity of human bone marrow and the prevalence of osteoblastic progenitors. J Orthop Res 19:117-125

Nawata M et al (2005) Use of bone morphogenetic protein 2 and diffusion chambers to engineer cartilage tissue for the 
repair of defects in articular cartilage. Arthritis Rheum 52:155-163

Neshati Z, Bahrami AR, Eshtiagh-Hosseini H, Matin MM, Housaindokht MR, Tabari T, Edalatmanesh MA (2012) Evaluating the biodegradability of Gelatin/Siloxane/Hydroxyapatite (GS-Hyd) complex in vivo and its ability for adhesion and proliferation of rat bone marrow mesenchymal stem cells. Cytotechnology 64:485-495. https://doi. org/10.1007/s10616-012-9426-5

Nguyen H, Qian J, Bhatnagar R, Li S (2003) Enhanced cell attachment and osteoblastic activity by $\mathrm{P}-15$ peptidecoated matrix in hydrogels. Biochem Biophys Res Commun 311:179-186

Panetta NJ, Gupta DM, Quarto N, Longaker MT (2009) Mesenchymal cells for skeletal tissue engineering. Panminerva Med 51:25-41

Partridge K et al (2002) Adenoviral BMP-2 gene transfer in mesenchymal stem cells in vitro and in vivo bone formation on biodegradable polymer scaffolds. Biochem Biophys Res Commun 292:144-152

Pisciotta A et al (2015) Human dental pulp stem cells (hDPSCs): isolation, enrichment and comparative differentiation of two sub-populations. BMC Dev Biol 15:14. https://doi.org/ 10.1186/s12861-015-0065-x

Pountos I, Panteli M, Lampropoulos A, Jones E, Calori GM, Giannoudis PV (2016) The role of peptides in bone healing and regeneration: a systematic review. BMC Med 14:103. https://doi.org/10.1186/s12916-016-0646-y

Qian J, Bhatnagar R (1996) Enhanced cell attachment to anorganic bone mineral in the presence of a synthetic peptide related to collagen. J Biomed Mater Res Part A 31:545-554

Ribeiro LS, Dos Santos JN, Ramalho LM, Chaves S, Figueiredo AL, Cury PR (2015) Risk indicators for tooth loss in Kiriri Adult Indians: a cross-sectional study. Int Dent $\mathrm{J}$ 65:316-321. https://doi.org/10.1111/idj.12187

Rich L, Whittaker P (2005) Collagen and picrosirius red staining: a polarized light assessment of fibrillar hue and spatial distribution. Braz J Morphol Sci 22:1-12

Ricordi C et al (1992) Human islet isolation and allotransplantation in 22 consecutive cases. Transplantation 53:407-414

Rodwell VW, Kennelly PJ (2000) Protein:higher orders of structure. In: Murray RK, Granner DK, Mayes PA, Rodwell VW (eds) Harper's illustrated biochemistry, 26th edn. Lange medical books/McGraw-Hill, London

Saha S, Kundu B, Kirkham J, Wood D, Kundu SC, Yang XB (2013) Osteochondral tissue engineering in vivo: a comparative study using layered silk fibroin scaffolds from mulberry and nonmulberry silkworms. PLoS ONE 8:e80004. https://doi.org/10.1371/journal.pone.0080004

Sarahrudi K, Mousavi M, Grossschmidt K, Sela N, König F, Vécsei V, Aharinejad S (2008) Combination of anorganic bovine derived hydroxyapatite with binding peptide does not enhance bone healing in a critical size defect in a rabbit model. J Orthop Res 26:759-763

Scarano A, Iezzi G, Petrone G, Orsini G, Degidi M, Strocchi R, Piattelli A (2003) Cortical bone regeneration with a synthetic cell-binding peptide: a histologic and histomorphometric pilot study. Implant Dent 12:318

Scaria PV, Sorensen KR, Bhatnagar RS (1989) Expression of a reactive molecular perspective within the triple helical region of collagen. Paper presented at the American Peptide Symposium

Schwartz MA (2010) Integrins and extracellular matrix in mechanotransduction. Cold Spring Harb Perspect Biol 2:a005066. https://doi.org/10.1101/cshperspect.a005066

Sollazzo V, Palmieri A, Girardi A, Farinella F, Carinci F (2009) Early effects of P-15 on human bone marrow stem cells. J Oral Maxillofac Res. 1:e4

Spiesz EM, Kaminsky W, Zysset PK (2011) A quantitative collagen fibers orientation assessment using birefringence measurements: calibration and application to human osteons. J Struct Biol 176:302-306. https://doi.org/10. 1016/j.jsb.2011.09.009

Spinella-Jaegle S et al (2001) Opposite effects of bone morphogenetic protein-2 and transforming growth factor-[beta] 1 on osteoblast differentiation. Bone 29:323-330

Squillaro T, Peluso G, Galderisi U (2016) Clinical trials with mesenchymal stem cells: an update. Cell Transplant 25:829-848. https://doi.org/10.3727/096368915X689622

Thorwarth M, Schultze-Mosgau S, Wehrhan F, Kessler P, Srour S, Wiltfang J, Andreas Schlegel K (2005) Bioactivation of an anorganic bone matrix by $\mathrm{P}-15$ peptide for the promotion of early bone formation. Biomaterials 26:5648-5657

Ting M, Jefferies SR, Xia W, Engqvist HA, Suzuki JB (2016) Classification and effects of implant surface modification on the bone: human cell-based in vitro studies. J Oral Implantol. https://doi.org/10.1563/aaid-joi-D-16-00079

Traini T, Pecora G, Iezzi G, Piattelli A (2006) Preferred collagen fiber orientation human peri-implant bone after a short- and long-term loading period: a case report. J Oral Implantol 32:177-181. https://doi.org/10.1563/285.1

Ullah M, Hamouda H, Stich S, Sittinger M, Ringe J (2012) A reliable protocol for the isolation of viable, chondrogenically differentiated human mesenchymal stem cells from high-density pellet cultures. Biores Open Access 1:297-305. https://doi.org/10.1089/biores.2012.0279

Vastardis S, Yukna RA, Mayer ET, Atkinson BL (2005) Periodontal regeneration with peptide-enhanced anorganic bone matrix in particulate and putty form in dogs. J Periodontol 76:1690-1696

Warren SM et al (2001) Hypoxia regulates osteoblast gene expression. J Surg Res 99:147-155

Weisgerber DW, Erning K, Flanagan CL, Hollister SJ, Harley BA (2016) Evaluation of multi-scale mineralized collagenpolycaprolactone composites for bone tissue engineering. J Mech Behav Biomed Mater 61:318-327. https://doi.org/ 10.1016/j.jmbbm.2016.03.032

$\mathrm{Xu}$ Y et al (2000) Multiple binding sites in collagen type I for the integrins 11 and 2 1. J Biol Chem 275:38981

Yamada Y, Nakamura S, Ito K, Sugito T, Yoshimi R, Nagasaka T, Ueda M (2010) A feasibility of useful cell-based therapy by bone regeneration with deciduous tooth stem cells, dental pulp stem cells, or bone-marrow-derived mesenchymal stem cells for clinical study using tissue engineering technology. Tissue Eng Part A 16:1891-1900

Yamada Y, Nakamura S, Klein OD, Ito K (2014) Current trends in stem cell therapy for improvement of bone quality. Histol Histopathol 29:691-697

Yamada Y, Nakamura-Yamada S, Kusano K, Baba S (2019) Clinical potential and current progress of dental pulp stem cells for various systemic diseases in regenerative 
medicine: a concise review. Int J Mol Sci. https://doi.org/ 10.3390/ijms20051132

Yang XB, Roach HI, Clarke NMP, Howdle SM, Quirk R, Shakesheff KM, Oreffo ROC (2001) Human osteoprogenitor growth and differentiation on synthetic biodegradable structures after surface modification. Bone 29:523-531. https://doi.org/10.1016/S87563282(01)00617-2

Yang X et al (2003) Induction of human osteoprogenitor chemotaxis, proliferation, differentiation, and bone formation by osteoblast stimulating factor-1/pleiotrophin: osteoconductive biomimetic scaffolds for tissue engineering. J Bone Miner Res 18:47-57. https://doi.org/10.1359/ jbmr.2003.18.1.47

Yang XB, Bhatnagar RS, Li S, Oreffo ROC (2004) Biomimetic collagen scaffolds for human bone cell growth and differentiation. Tissue Eng 10:1148-1159
Yoshii T et al (2009) Isolation of osteogenic progenitor cells from trabecular bone for bone tissue engineering. Tissue Eng Part A 16:933-942

Yu HS, Noh WC, Park JW, Lee JM, Yang DJ, Park KB, Suh JY (2011) Comparative study on the cellular activities of osteoblast-like cells and new bone formation of anorganic bone mineral coated with tetra-cell adhesion molecules and synthetic cell binding peptide. J Periodontal Implant Sci 41:293-301. https://doi.org/10.5051/jpis.2011.41.6.293

Yuan K, Huang JS, Hsu CW, Hung IJ (2007) A mineralization associated membrane protein plays a role in the biological functions of the peptide coated bovine hydroxyapatite. J Periodontal Res 42:420-428

Publisher's Note Springer Nature remains neutral with regard to jurisdictional claims in published maps and institutional affiliations. 